\title{
Is anybody listening? The impact of second home ownership on local governments in Australia and elsewhere
}

\author{
Chris Paris $^{\mathrm{a}}$ \\ ${ }^{a}$ Research Fellow, Centre for Housing, Urban and Regional Planning, \\ University of Adelaide, Australia; Emeritus Professor of Housing, University of \\ Ulster, UK, chris.paris@adelaide.edu.au
}

\begin{abstract}
This paper reflects on aspects of changing national and international housing markets, especially the impacts of the growth of second (and multiple) home ownership on particular places. It is argued that research and commentary on second home ownership has not yet adequately understood or analysed the combined effects of a range of processes of change, including retirement migration, seasonal movements between multiple homes, and the role of overseasbased purchasers of second (and multiple) homes. The impacts vary enormously between places, but in almost every case they generate a range of demands, problems, issues and opportunities for local governments. Examples range from the demand for service provision in inner London to problems of dealing with the legacy of failed second homes developments within the housing market crashes in Ireland and the Spanish Costas.
\end{abstract}

\section{Introduction}

This paper develops the author's interest on second homes though a comparison between the situation in Australia and examples from the UK and Ireland. The author has worked on this topic over the last 15 years in the UK, Ireland and Australia and has also examined material from many other countries (Paris 2011). The term 'second homes' here refers to dwellings are typically called 'holiday homes' in Australia; not households' 'primary residences' nor properties that are rented to tenants. This definition includes dwellings that are used as a base during the working week as a pied-ả-terre, but excludes dwellings used occasionally by their owners but which primarily are rented to holiday makers. Many owners of second homes own more than one such dwelling purely for use by themselves, their families or friends; in these cases I refer to the ownership of ‘multiple homes’ or 'multiple residences’ (Paris 2012). 
The need for careful definitions reflects the distinctive nature of second homes as the term refers to how dwellings are used, rather than particular types of dwelling. Dwellings are often used in different ways over time and may be used in different ways at different seasons of the year. The tax treatment of second home ownership varies between countries. They are subject to capital gains tax in most countries, though any tax advantages or disadvantages relating to occasional rental of holiday homes to other users vary considerably.

Attitudes towards second homes also vary between countries. They often are blamed for destroying rural communities in the UK, resulting in 'ghost villages' largely unoccupied during the week, and for causing house price inflation in low income areas. The situation is very different in many other European countries where second home ownership has been established more widely across societies and for longer than in the UK; for example levels of second home ownership are very high in Nordic countries. Second home ownership also had become well established in the USA, Canada, New Zealand and Australia by the 1970s.

The growth of second home ownership has many implications for local government, especially in localities within which demand is most concentrated, especially because it often occurs in combination with other processes of change, including the growth of long-distance and seasonal commuting, high levels of mobility among affluent second home owners, declining employment in primary industries and growth of new forms of work, retirement migration and, in some cases, growing transnational purchase of second (and multiple) residences. The impacts vary enormously between places, but in almost every case they generate a range of demands, problems, issues and opportunities for local governments. Many of these impacts remain significantly under-researched and their impacts are under-appreciated. For example, many Australian local governments experience difficulties related to service provision during periods of peak seasonal use as their rate support from state governments is based only on their 'permanent' populations as recorded in the census (Mackenzie et al. 2008).

\section{Second home ownership in the UK and Ireland}

The growth of second home ownership in the UK and Ireland has been more recent and faster than Australia. The main drivers of growing second home ownership in both countries were the same: rapidly growing affluence and mobility combined with a strong preference for property ownership. Second home ownership was a major element in the lifetime investment and consumption strategies of affluent households, including tax minimisation strategies and building superannuation portfolios (Paris 2013a). 
Despite these commonalities, there have been numerous differences between the UK and Ireland in terms of second home ownership since the early 1990s. The context and character of growth of second home ownership differed considerably between the UK and Ireland during the boom years to 2007. The quality of official data on second homes also varied enormously. There is good survey-based official data on English second home ownership since the early 1990s. Developments in other parts of the UK are less well documented, though census data and some local government property-related data provide useful indicators of change. There is no specific official Irish data on second homes and census-based data is very limited, so it is hard to estimate the number of second homes with any degree of precision. Differences between the UK and Ireland regarding second home ownership, moreover, have become much greater since the Global Financial Crisis (GFC) (Paris 2013a).

The UK has one of the most restrictive planning regimes in the world, whereas Ireland has an extremely laissez faire planning regime. The British planning system has largely stopped new rural housing development, so the growth of second home ownership within the UK has largely involved gentrification and diversification of forms of development to fit within the tight regulatory planning regime. In Ireland, by way of contrast, the growth of second home ownership largely involved the construction of new dwellings in coastal and countryside areas, with very little rural gentrification.

The English data show that second home ownership doubled between the early 1990s and 2007, with the highest concentrations of second homes within the UK in or near: designated National Parks, especially the Lake District; Areas of Outstanding Natural Beauty (AONBs); high amenity rural areas such as the Cotswolds; and attractive coastal areas, especially Devon, Cornwall and Norfolk. But the fastest growth took place outside Britain, initially mainly in France and Spain but increasingly across a much wider geographical canvas. English second home ownership continued to grow strongly after the GFC, albeit at a slightly lower rate than in the period 2000-2007. English second home ownership continued to expand more overseas than within the UK, though high demand in popular coastal and other high amenity areas spilled across into previously lower-demand areas.

One distinctive feature of second home ownership in England has been strong growth of second homes in urban areas, especially in London; mainly pieds-à-terre for affluent households with other homes outside the cities. In addition, there has been strong growth of overseas-based ownership of homes in the UK, especially in prime inner London areas such as Belgravia, Kensington and Chelsea, most notably in 'Billionaires Row' (Kensington Palace Gardens). House prices in these prime areas of London have 
continued to grow strongly over the last few years, in marked contrast to much of the UK where they have been static or fallen slightly compared to 2007 prices (Paris 2013b).

Second homes had been a substantial element of the Irish housing boom from the mid-1990s to 2007, especially in coastal areas, in many cases encouraged by generous tax breaks for owners and developers (Norris et al. 2010). Since 2007, however, there has been no discernible growth of second home ownership in Ireland and dwellings constructed for the second homes market have been a large element of the bursting of the Irish housing bubble. Thousands of homes lie empty and deteriorating in 'ghost estates' across the country, especially along the Atlantic seaboard and areas with relatively high rates of second homer ownership (Kitchen et al. 2010). Unlike London, Dublin house prices have fallen at least as much as prices across the rest of the country, overall by more than $40 \%$ since 2007.

The situation in Ireland has parallels in other areas where second homes development figured prominently in unsustainable housing development booms, most notably in parts of Spain where massive over-development was followed by collapsing house prices and abandonment of unfinished housing developments (Paris 2011). The main difference between Ireland and Spain in this regard was the much higher proportion of overseasbased second home owners in the Spanish Costas, many of whom also had major problems with changing exchange rates.

\section{Second home ownership in Australia: shacks, holiday homes and mansions}

There is a substantial Australian literature on second homes, mainly within leisure studies or planning, and recently often within debates about sea change. As in New Zealand, mass second home ownership came earlier than in the UK or Ireland, but growth was much less rapid over the period from around 1990 to 2007. Many early second homes were vernacular self-built shacks, in some cases on land subsequently eaten up by suburban expansion, in others on Crown land, typically unserviced coastal allotments. Increasingly, however, second homes have been developed commercially, involving some gentrification of former lower quality dwellings, and developer-led mixed use resorts or marinas. New upmarket second homes selling for over \$1 million are described as 'shacks' for marketing purposes.

There is no good official data on the number or characteristics of Australian second homes. They are not identified in census or housing surveys, so numbers have to be inferred on the basis of census data on empty dwellings complemented by local government data on the numbers and other addresses of non-resident ratepayers. One 
recurring problem is that census data on empty dwellings and councils' data on nonresident ratepayers cannot differentiate between dwellings that are primarily used as holiday homes by their owners as opposed to dwellings that are primarily available for short-term lettings by holiday makers or weekenders. Other sources of evidence include visitor and tourism surveys as well as local qualitative or anecdotal data. It is likely that many Australians own holiday homes overseas, though this is probably much less common than in the UK. It is equally likely that there is less non-domestic ownership of second homes within Australia, though the author suspects that this may be growing quite rapidly. One cannot use census data to separate out second homes from other elements of 'sea/tree change' areas occupied for varying periods of time by mobile populations. Allowing for a considerable range of possible error, the author's best estimate of the current number of holiday homes in Australia is at least 500,000.

\section{Australian holiday home places}

There is certainly sufficient available evidence to enable the identification of places in Australia within which there are high numbers of holiday homes. Permanent residents in areas such as local government officials and elected representatives are well aware of seasonal variations in population numbers and service use. The most obvious examples are popular coastal areas within easy access of all capital cities, as well as highland areas popular for winter sports (the Snowy Mountains) or for trout fishing (Central Highlands of Tasmania). In all cases, though, second homes are mixed in with holiday rental properties as well as other dimensions of sea/tree change processes.

Few studies have looked specifically at local governments and second homes. Frost (2003; 2004) reviewed census and other data on vacant properties in Melbourne's 'second homes belt'. Over 50\% of dwellings were vacant on census night 1996 in 14 coastal towns, mainly 75-125 km from Melbourne’s CBD. He reported little evidence of conflicts between second home owners and 'locals'. Indeed, he suggested that some second home owners 'see themselves as established (or 'local') in comparison with newcomers or other tourists'.

More recently, Paris (2011) reviewed 2006 census data for the same area and identified both continuity and change in this second homes belt since 1996. There had been strong growth in the number of dwellings overall (26\%) and the resident population (27\%) in the 10 largest towns. The number of dwellings recorded as unoccupied grew in number (23\%) but fell as a proportion of all dwellings, implying that there had been net movement into these towns on a permanent basis. This may well include former second home owners moving in on a permanent basis as well as new in-migrants between 1996 and 2006. There were some significant differences between the top 10 second home 
towns during the inter-censal period. The resident population grew most in Cowes (38\%) - more than twice as much as the lowest growth town of Anglesea (15\%). Venus Bay stood out with above average growth in its resident population, total dwellings and unoccupied dwellings. Thus the census data reveal diversity rather than a single motion of change.

The author does not know of any studies in Australia either of urban (as in metropolitan) second homes or of overseas-based second home ownership in Australia by owners based overseas. It is extremely likely, however, that both are widespread albeit unrecorded within official housing data sets. The combination of the known diversity of second home ownership within Australia, and high probability that much second home ownership is unrecorded or misunderstood, is crying out for further investigation and analysis.

There are many issues and questions to be explored, regarding local government in particular. How can problems of fiscal imbalance be resolved with LGAs in second homes hot spots that are only being funded by state governments on the basis of their 'resident' population? How best can under-funded LGAs deal with highly seasonal demand for service provision? What are the environmental impacts of large scale commercial second homes developments? Will ageing second home owners retire to their second homes, use them more, or dispose of them? Are there growing conflicts between affluent second home owners and other residents in hot-spot areas, as in parts of England? How many dwellings recorded by the census or records of non-resident ratepayers are holiday homes as opposed to holiday rentals? Are there risks of overproduction, as in Ireland and Spain? What is the extent of second home ownership within metropolitan areas? Is there growing overseas demand for second homes in Australia, for example from China or Singapore? If so, and it seems highly likely, then what are the implications of this?

\section{Conclusions}

Many issues relating to second homes in Australia remain largely unexplored and under-reported. Some are of particular relevance to local governments, especially councils in hot-spot areas: they expected to provide services to cope with peak seasonal demand but their funding by state governments does not recognise the significance of highly varying non-resident populations. There are many other unresolved and unasked questions that the author believes are worthy of much further research. 


\section{References}

Frost, W. 2003, Second homes in Australia: an exploration of statistical sources, Working Paper 81/03, Monash University Faculty of Business and Economics, Melbourne.

Frost, W. 2004, 'A hidden giant: second homes and coastal tourism in south-eastern Australia', in C.M. Hall \& D. Müller (eds.), Tourism, Mobility and Second Homes, Channel View Publications, Clevedon, UK, pp. 162-73.

Kitchen, R., Gleeson, J., Keaveney, K. \& O’Callaghan, C. 2010, A Haunted Landscape: Housing and Ghost estates in Post-Celtic Tiger Ireland, NISRA Working Paper 59, National University of Maynooth, Maynooth.

McKenzie, F., Martin, J., Paris, C. \& Reynolds, J. 2008, 'Fiscal policy and mobility: the impact of multiple residences on the provision of place-based service funding', Australasian Journal of Regional Studies, vol. 14, no. 1, pp 53-72.

Norris, M., Paris, C. \& Winston, N. 2010, 'Second homes within Irish housing booms and busts: North-South comparisons, contrasts and debates', Environment and Planning C: Government and Policy, vol. 28, no. 4, 666-80.

Paris, C. 2011, Affluence, Mobility and Second Home Ownership, Routledge, London.

Paris, C. 2012, 'Multiple homes', in S. Smith (ed.), The International Encyclopedia of Housing and Home, Elsevier, Oxford.

Paris, C. 2013a, 'Second home ownership in the UK Kingdom and Ireland since the global financial crisis', in Z. Roca (ed.), Second Home Tourism in Europe: Lifestyle Issues and Policy Responses, Ashgate, Aldershot.

Paris, C. 2013b, 'The super-rich and the globalisation of prime housing markets', Housing Finance International, Summer 2013, pp. 18-27.

Paris, C., Jorgensen, B. \& Martin, J. 2009, ‘The ownership of many homes in Ireland and Australia: issues for states and localities', Australasian Journal of Regional Studies, vol. 15, no. 1, pp. 65-80. 